\title{
PELATIHAN TEST OF ENGLISH FOR INTERNATIONAL COMMUNICATION (TOEIC) BAGI MAHASISWA POLITEKNIK NEGERI JEMBER
}

\author{
Alfi Hidayatu Miqawati ${ }^{1}$, Fitri Wijayanti ${ }^{1}$, Agus Setia Budi ${ }^{1)}$, Cholimatus Zuhro ${ }^{1)}$, Nila Susanti ${ }^{1)}$ \\ ${ }^{1)}$ Program Studi Bahasa Inggris, Jurusan Bahasa, Komunikasi dan Pariwisata, Politeknik Negeri Jember, Jember, \\ Jawa Timur, Indonesia \\ Corresponding author : Alfi Hidayatu Miqawati \\ E-mail : alfi_hidayatu@polije.ac.id
}

Diterima 14 Juli 2021, Direvisi 22 Juli 2021, Disetujui 23 Juli 2021

\begin{abstract}
ABSTRAK
Bahasa Inggris menjadi salah satu keterampilan yang harus dikuasai oleh mahasiswa agar dapat terjun ke dunia kerja global. Banyak perusahaan mensyaratkan penguasaan bahasa asing, salah satunya adalah bahasa Inggris. Untuk menjawab tantangan tersebut, Politeknik Negeri Jember (Polije) mengadakan uji kompetensi bahasa Inggris Test of English for International Communication (TOEIC) untuk mahasiswa tingkat akhir sebagai salah satu syarat kelulusan. Namun, permasalahan utama yang dihadapi mahasiswa yang akan mengikuti tes tersebut adalah mereka belum mengetahui TOEIC. Tujuan dari kegiatan pengabdian kepada masyarakat ini adalah untuk meningkatkan pengetahuan mitra tentang TOEIC melalui sosialisasi dan pelatihan TOEIC yang melibatkan 65 mahasiswa Polije. Hasil dari pelatihan TOEIC menunjukkan bahwa mahasiswa dapat (1) meningkatkan pemahaman tentang TOEIC, (2) mengimplementasikan strategi yang sesuai dalam mengerjakan soal TOEIC, (3) dapat meningkatkan kemampuan Bahasa Inggris mereka. Kegiatan serupa direkomendasikan melibatkan lebih banyak mahasiswa di lingkungan Polije agar mahasiswa Polije lebih siap mengikuti uji kompetensi bahasa Inggris dan bersaing di dunia global.
\end{abstract}

Kata kunci: pelatihan; TOEIC; komunikasi; keterampilan; bahasa inggris.

\begin{abstract}
English is one of the skills that must be mastered by students in order to enter the global world of work. Many companies require mastery of foreign languages, one of which is English. To answer this challenge, Politeknik Negeri Jember (Polije) held an English competency test; Test of English for International Communication (TOEIC) for senior students as one of their graduation requirements. However, the main problem faced by students who took the test was that they knew nothing about TOEIC. The purpose of this community service activity was to improve the students' knowledge about TOEIC through TOEIC socialization and training, which involved 65 students. The results of the TOEIC training showed that the students could (1) improve their understanding about TOEIC, (2) implement appropriate strategies in working on TOEIC questions, (3) improve their English skills. Similar activities are recommended by involving more students in Polije so that students of Polije are better prepared to take the English language competency test and compete in the global world.
\end{abstract}

Keywords: training; TOEIC; communication; skills; english.

\section{PENDAHULUAN}

Tuntutan zaman dan derasnya arus globalisasi menuntut setiap individu untuk dapat berkompetisi dan memiliki daya saing tinggi baik di tingkat lokal, regional, nasional, dan internasional. Agar dapat memiliki daya saing yang tinggi, berbagai macam keterampilan diperlukan, salah satunya adalah keterampilan berkomunikasi dalam bahasa asing, salah satunya Bahasa Inggris. Hal ini dikarenakan dalam pasar/dunia kerja global, perusahaan cenderung merekrut tenaga/karyawan baru yang menguasai bahasa Inggris.
Salah satu jenis tes yang mengalami peningkatan popularitas dan permintaan pasar adalah TOEIC (Test of English for International Communication). TOEIC merupakan tes yang dikembangkan oleh Educational Testing Service (ETS) dan digunakan untuk mengukur kemampuan Bahasa Inggris seseorang dalam konteks dunia kerja/workplace context dan bukan penutur asli bahasa Inggris (ETS, 2019); (Powers \& Powers, 2015). Skor TOEIC dapat menjadi rekomendasi untuk proses perekrutan, penempatan dan promosi karyawan, mengukur kemampuan bahasa English, mengevaluasi progress dalam bahasa Inggris (ETS, 2019); 
(Ito, T., Kawaguchi, K., \& Ohta, 2005). Tes TOEIC terdiri dari Listening and Reading (TOEIC LR) dan Speaking and Writing (TOEIC SW). Peserta tes dapat memilih untuk mengikuti kedua TOEIC LR dan TOEIC SW atau memilih TOEIC LR dengan TOEIC Speaking atau TOEIC Writing (Liu \& Costanzo, 2013); (Im \& Cheng, 2019).. Bagi peserta yang belum familiar dengan tes tersebut, diperlukan sebuah upaya agar reliabilitas hasil tes dapat tinggi dan dapat menunjukkan performa peserta yang sebenarnya.

Berbagai upaya dilakukan agar peserta didik dapat memiliki keterampilan yang diperlukan industri. Dalam konteks penguasaan bahasa asing dan persiapan mahasiswa untuk terjun ke dunia kerja, Politeknik Negeri Jember, sebagai salah satu pendidikan vokasi di Indonesia, memiliki program uji kompetensi bahasa Inggris sebagai salah satu persyaratan kelulusan mahasiswa. Tes yang digunakan adalah TOEIC LR. Namun, mahasiswa tingkat akhir yang akan mengikuti tes tersebut menyebutkan jika mereka tidak siap mengikuti TOEIC karena mereka belum mengetahui jenis soal dan cara mengerjakan soal dengan efektif. Ketidakpahaman akan tipe dan cara pengerjaan tes dapat mempengaruhi hasil performa mahasiswa.

Sebagaimana disampaikan oleh (Takahashi, 2012) bahwa perguruan tinggi sebagai pos terakhir dalam mempersiapkan peserta didik dalam jenjang pendidikan formal harus dapat menjawab tuntutan industri tersebut dan harus mempersiapkan mahasiswanya mempelajari TOEIC agar dapat memperoleh nilai memuaskan dalam penempatan kerja. Sehingga, kegiatan untuk mempersiapkan mahasiswa Politeknik Negeri Jember mengikuti uji kompetensi bahasa Inggris diperlukan.

Mitra dari kegiatan Pengabdian kepada Masyarakat (PkM) ini adalah mahasiswa tingkat akhir Program Studi D3 Bahasa Inggris yang akan mengikuti tes kompetensi bahasa Inggris. Studi pendahuluan dilakukan melalui wawancara dan observasi kepada pihak mitra untuk mengidentifikasi permasalahan yang dihadapi mitra. Tim pelaksana kegiatan PkM berhasil mengidentifikasi beberapa permasalahan yang dihadapi oleh mitra. Permasalahan yang dihadapi oleh mitra antara lain bahwa mitra masih belum mengenal TOEIC, sehingga diperlukan suatu kegiatan untuk mengenalkan dan meningkatkan pengetahuan tentang TOEIC dan ketrampilan Bahasa Inggris mitra. Melalui kegiatan pelatihan dan pengenalan tes TOEIC ini. mitra yang mejadi peserta pelatihan diharapkan dapat mengetahui informasi seputar TOEIC, menjawab soal-soal latihan dengan benar, dan meningkatkan kemampuan bahasa Inggris mereka.

\section{METODE}

Metode yang digunakan adalah pelatihan dengan cara memberikan pengenalan materi TOEIC (Test of English as International Communication). Pelaksanaan kegiatan pelatihan terbagi dalam beberapa tahapan, koordinasi awal dengan mitra, penyusunan materi dan media pelatihan, pelaksanaan pelatihan, dan evaluasi kegiatan.

\section{Koordinasi awal dengan mitra}

Sebelum pelaksanaan kegiatan pelatihan, hal pertama yang dilakukan adalah koordinasi dengan mitra. Koordinasi dilakukan untuk memastikan jadwal dan jumlah anggota mitra yang akan mengikuti kegiatan pelatihan pengenalan materi TOEIC. Kegiatan ini juga dilakukan untuk mempertegas komitmen mitra dan tim pelaksana kegiatan dalam mengikuti dan melaksanakan pelatihan.

\section{Penyusunan Materi Pelatihan}

Materi pelatihan disusun dengan mengadopsi materi dari beberapa sumber yang dibagi menjadi dua jenis materi, yaitu 1) penjabaran umum tentang TOEIC dan strategi dalam menjawab soal Listening, Grammar, dan Reading dalam TOEIC dan 2) soal latihan dan pembahasannya.

Media juga diperlukan untuk mempermudah penyampaian pesan dalam pelatihan. Dalam pelatihan ini, media dan alat bantu yang berbeda dugunakan di setiap sesi materi yang disampaikan, diantaranya laptop, LCD proyektor, Speaker (Pengeras Suara), dan flipchart paper.

\section{Pelaksanaan Pelatihan}

Kegiatan pelatihan pengenalan TOEIC dilaksanakan selama 6 pertemuan setiap hari Sabtu dan Minggu. Metode yang digunakan adalah pembelajaran yang berpusat pada pebelajar (Student-Centred Learning) dan diharapkan mitra dapat menguasai materi yang disampaikan dengan baik dan mengerjakan soal-soal latihan TOEIC dengan benar.

Partisipasi mitra dalam kegiatan ini berupa 1) memberikan informasi yang diperlukan, 2) menyediakan tempat dan mempersiapkan kelas untuk pelatihan, 3) mengkoordinir anggota mitra untuk mengikuti pelatihan sesuai jadwal (bagi ketua mitra). Jadwal kegiatan pelatihan dapat dilihat pada Tabel 1. 
Tabel 1. Jadwal Kegiatan Tabel.

\begin{tabular}{cc}
\hline Pertemuan ke- & Kegiatan \\
\hline 1 & Pretest \\
\hline 2 & Overview TOEIC \\
\hline 3 & $\begin{array}{c}\text { Listening } \\
\text { Expring (Written } \\
\text { Exprion) }\end{array}$ \\
\hline 5 & Reading (Texts) \\
\hline 6 & Posttest \\
\hline
\end{tabular}

\section{Evaluasi Hasil Pelatihan}

Evaluasi dilakukan untuk melihat ketercapaian target dan luaran yang diharapkan, yakni kemampuan peserta pelatihan dalam menjawab soal-soal TOEIC. Data yang diperoleh akan dianalisa secara kuantitatif untuk melihat peningkatan pemahaman dan keterampilan berdasarkan apa yang telah mereka peroleh selama kegiatan pelatihan. Selain tu, peserta juga diminta untuk mengisi angket guna mengetahui persepsi mereka tentang kegiatan yang telah dilaksanakan.

\section{HASIL DAN PEMBAHASAN}

Kegiatan Pengabdian kepada

Masyarakat (PkM) ini dilaksanakan berdasarkan studi pendahuluan yang telah dilakukan. Beberapa tahapan dilakukan agar tujuan dari kegiatan dapat tercapai. Kegiatan ini diawali dengan mengadakan koordinasi awal dengan pihak mitra. Koordinasi yang dilakukan meliputi 1) pendataan jumlah peserta yang bersedia mengikuti kegiatan pelatihan, 2) penyusunan jadwal pelatihan, 3) tempat pendampingan pembelajaran TOEIC, dan 4) evaluasi pembelajaran TOEIC. Pada tahap ini, peran mitra adalah mengkoordinir semua mahasiswa yang bersedia mengikuti kegiatan pelatihan ini sesuai dengan jadwal yang telah disepakati.

$$
\text { Kegiatan selanjutnya adalah }
$$

penyusunan media dan materi pelatihan. Hal ini dilakukan dengan melakukan kajian literatur sehingga materi yang disusun dapat mengakomodir semua kebutuhan mitra. Materi terbagi menjadi dua bagian, listening dan reading. Materi listening meliputi monologues, short dialogues, dan talks. Materi reading meliputi written expression (grammar), filling the blanks, dan functional texts. Media pembelajaran juga dikembangkan agar mahasiswa yang mengikuti pelatihan dapat memahami materi dengan mudah, diantaranya audio untuk listening, file ppt, dan flashcards. Tim pelaksana juga menyusun angket untuk mengetahui persepsi mitra tentang pengetahuan mereka tentang TOEIC dan pelaksanaan kegiatan secara keseluruhan. Selain itu, tim pelaksana juga menyiapkan 1 (satu) jenis materi untuk pretest dan posttest beserta kunci jawaban dan konversi nilainya.

Pelaksanaan kegiatan pengenalan dan pelatihan ini adalah 6 pertemuandan dilaksanakan pada setiap hari Sabtu dan Minggu selama 6 jam untuksetiap pertemuannya. pukul $08.00-11.00$. Pada awal pertemuan, tim pelaksana memberikan informasi umum (overview) TOEIC dan untuk apa test ini diberikan kepada mitra. Jumlah peserta yang mengikuti kegiatan ini sebanyak 65 mahasiswa. Kegiatan ini dilakukan dengan metode ceramah dan tanya jawab. Peserta sangat antusias dan terlibat secara aktif dengan menanyakan hal-hal umum tentang TOEIC, seperti apakah TOEIC juga bisa diakui sebagai persyaratan pendaftaran beasiswa, industri/institusi apa saja yang menggunakan TOEIC untuk seleksi dan promosi karyawan, dan apa saja perbedaan-perbedaan TOEIC dibandingkan jenis tes berstandar lainnya seperti IELTS dan TOEFL. Setelah overview, peserta mengisi angket untuk mengetahui pengalaman dan pengetahuan mereka tentang TOEIC.

Pelaksana membagi materi TOEIC menjadi 2 (dua) bagian; Listening dan Reading. Kegiatan pelatihan dilaksanakan dengan metode Student-Centered Learning (SCL) berupa Communicative Language Teaching (CLT) untuk mengoptimalkan partisipasi dan keterlibatan aktif peserta selama proses pelatihan dan meningkatkan keterampilan peserta. (Kim, 2010) menyebutkan bahwa penggunaan CLT memungkinkan untuk digunakan dalam kelas persiapan tes karena dapat membantu siswa memperoleh pengetahuan tentang tes secara bermakna. Di tahap ini, peserta menemui kesulitan untuk mengidentifikasi pilihan jawaban yang tepat, mengenali tipe soal, dan mengerjakan soal agar waktu yang tersedia tidak terbuang hanya di beberapa soal atau bagian saja. Cara pengerjaan soal TOEIC di dua bagian ini disampaikan agar peserta nantinya dapat menyelesaikan soal dengan baik dan mempertimbangkan efisiensi waktu dalam pengerjaan soal-soal yang ada. Latihan pengerjaan soal juga mengkombinasikan latihan soal berbasis pen and paper dan aplikasi berbasis android (Mobile Assissted Language Learning/MALL). Penggunaan aplikasi berbasis android dalam pembelajaran dapat meningkatkan partisipasi dan sikap positif (Miqawati, 2020). Setelah kegiatan pelatihan berakhir, pada pertemuan selanjutnya peserta mengisi angket dan mengerjakan posttest.

Hasil evaluasi angket di pertemuan pertama diperoleh kesimpulan bahwa peserta belum mengetahui dan belum pernah 
mempelajari TOEIC. Dikarenakan materi TOEIC ini merupakan hal dan pengalaman baru bagi mereka, mereka sangat antusias untuk hadir dan mengikuti kegiatan pelatihan dengan penuh semangat. Hal ini dibuktikan dengan tingginya tingkat kehadiran selama kegiatan pelatihan, yakni rata-rata sebesar 90\% (59 orang).

Adapun hasil analisis angket setelah pelatihan menunjukkan persepsi mitra bahwa mereka mendapatkan pengalaman baru dan tambahan pengetahuan sehingga mereka lebih mengetahui secara mendalam tentang TOEIC dan strategi dalam mengerjakannya. Mereka juga berharap kegiatan-kegiatan serupa dapat dilaksanakan di lain kesempatan agar semakin meningkatkan pengetahuan dan keterampilan bahasa Inggris mereka.

Kegiatan evaluasi ini dilakukan untuk menganalisa keberhasilan program dan untuk mengidentifkasi rencana keberlanjutan program berikutnya. Dari hasil tes, angket, dan tingkat kehadiran, tim pelaksana menyimpulkan bahwa kegiatan pelatihan TOEIC telah berhasil memberikan solusi atas permasalahan yang dihadapi mitra. Pada akhirnya, mitra atau peserta pelatihan dapat memahami pengertian dan tujuan pelaksanaanTOEIC. Selain itu, mitra dapat meningkatkan kemampuan Bahasa Inggris serta mereka mampu menguasai strategi dalam mengerjakan soal - soal TOEIC. Hal ini selaras dengan (Wijayanti \& Miqawati, 2016) bahwa kegiatan pelatihan tes bahasa asing dan sejenisnya yang sesuai dengan permasalahan mitra di lapangan dapat meningkatkan pemahaman tentang suatu jenis tes, menerapkan strategi dalam pengerjaan soal, dan meningktakna kemampuan bahasa Inggris.

\section{SIMPULAN DAN SARAN}

Pelaksanaan pelatihan TOEIC bagi mahasiswa Politeknik Negeri Jember menghasilkan beberapa luaran, di antaranya adalah mitra atau peserta kegiatan dapat (1) meningkatkan pemahaman tentang TOEIC, (2) mengimplementasikan strategi yang sesuai dalam mengerjakan soal TOEIC, (3) dapat meningkatkan kemampuan Bahasa Inggris mereka. Untuk mencapai luaran tersebut, pelaksanaan kegiatan ini menggunakan variasi metode baik dalam penyampaian materi maupun dalam latihan pengerjaan soal. Pemilihan strategi yang berfokus pada peserta (Student Centered Learning/SCL) dan pembelajaran berbasis MALL dapat meningkatkan partisipasi dan pemahaman peserta pelatihan. Karena peserta pelatihan masih terbatas apada satu program studi di Politeknik Negeri Jember, pelatihan serupa dengan melibatkan lebih banyak peserta dari berbagai program studi disarankan untuk pengembangan dan peningkatan kompetensi mahasiswa, terutama mereka yang ebrada di tingkat akhir dan siap terjun ke dunia kerja.

\section{DAFTAR RUJUKAN}

ETS. (2019). Examinee Handbook - TOEIC $\AA$ LISTENING \& READING TEST. https://www.ets.org/s/toeic/pdf/examin ee-handbook-for-toeic-listeningreading-test-updated.pdf

Im, G. H., \& Cheng, L. (2019). The Test of English for International Communication (TOEIC $\AA$ ). Language Testing, 36(2), 315-324. https://doi.org/10.1177/026553221982 8252

Ito, T., Kawaguchi, K., \& Ohta, R. (2005). A Study of the Relationship between TOEIC Scores and Functional Job Performance: Self-assessment of Foreign Language Proficiency. TOEIC Research Report, 1-40. http://www.iibcglobal.org/library/redirect_only/library/t oeic_data/toeic_en/pdf/newsletter/1_E. pdf

Kim, J. (2010). Effective Communicative Language Teaching in a TestPreparation Class: Is It Possible? Hawaii Pacific University TESOL Working Paper Series, 8((1)), 39-43.

Liu, J., \& Costanzo, K. (2013). The Relationship Among TOEIC ® Listening, Reading , Speaking, and Writing Skills. The Research Foundation for the TOEIC Tests: A Compendium of Studies, $2(2$ September).

Miqawati, A. H. (2020). Pronunciation Learning, Participation, and Attitude Enhancement Through Mobile Assisted Language Learning (Mall). English Review: Journal of English Education, $8(2)$, https://doi.org/10.25134/erjee.v8i2.211 8

Powers, D. E., \& Powers, A. (2015). The incremental contribution of TOEIC® Listening, Reading, Speaking, and Writing tests to predicting performance on real-life English language tasks. Language Testing, 32(2), 151-167. https://doi.org/10.1177/026553221455 1855

Takahashi, J. (2012). An Overview of the Issues on Incorporating the TOEIC test into the University English Curricula in Japan. Tama University Global Studies Department Bulletin, 4(3), 127-138. 
Wijayanti, F., \& Miqawati, A. H. (2016). Pelatihan Test of English as A Foreign Language ( TOEFL ) Ekuivalen Anggota UKM E-Club Politeknik Negeri Jember. Prosiding, 177-180. 